\title{
VARIETAL RESPONSE OF MAIZE TO NITROGEN AND ZINC FERTILIZER IN MINNA SOUTHERN GUINEA SAVANNA OF NIGERIA
}

\author{
*Afolabi, S.G. ${ }^{1 \& 2}$, Ewulo, B.S. ${ }^{2}$, Aiyelari, O.P., ${ }^{2}$ Adeyemo, A.J. ${ }^{2}$
}

${ }^{1}$ Department of Soil Science and Land Management, School of Agriculture and Agricultural Technology, Federal University of Technology, Minna, Nigeria.

${ }^{2}$ Department of Crop, Soil and Pest Management, School of Agriculture and Agricultural Technology, Federal University of Technology, Akure, Nigeria.

*Correspondence: ooreoluwa14@gmail.com: afolabi.gbolahan@futminna.edu.ng.

\begin{abstract}
A field experiment was conducted in 2018 and 2019 seasons at the Teaching and Research Farm of the Federal University of Technology, Minna to determine the varietal response of maize to nitrogen and zinc fertilizer in Minna. The treatments included four levels of N: 0, 30, 60 and $90 \mathrm{~kg} \mathrm{ha}^{-1}$, three levels of $\mathrm{Zn:} 0,2.5$ and $5 \mathrm{~kg} \mathrm{ha}^{-1}$ and two varieties of maize (Oba Super 2 and Suwan-1-SR). The experimental design was a $4 \times 3 \times 2$ factorial design fitted in a randomized complete block design with three replications. The data collected were, plant height, number of leaves, cob weight, cob length, stover yield, grain yield and 1000 grain weight. All data collected were subjected to analysis of variance and the means were separated using Duncan Multiple Range Test. Highest plant height (43.69 and $44.37 \mathrm{~cm}$ ) were obtained in 60 and $90 \mathrm{~kg} \mathrm{~N} \mathrm{ha-1} \mathrm{treatment} \mathrm{application} \mathrm{respectively} \mathrm{in} \mathrm{year} 2018$ at 3 Week After Sowing (WAS), these heights were significantly different from that of control $(0 \mathrm{~kg}$ $\left.N \mathrm{ha}^{-1}\right)$. Zinc (Zn) fertilization has no significant effect on maize height at all growth stage of maize in year 2018. Application of Zn produced significantly taller plants than those without $\mathrm{Zn}$ application at 3 and 9 WAS in 2019. The treatment $60 \mathrm{~kg} \mathrm{~N} \mathrm{ha}^{-1}$ had significantly higher yield (27873.7 $\left.\mathrm{kg} \mathrm{ha}^{-1}\right)$ than others but similar to $90 \mathrm{~kg} \mathrm{~N} \mathrm{ha}^{-1}\left(2512.4 \mathrm{~kg} \mathrm{ha}^{-1}\right)$. Application of

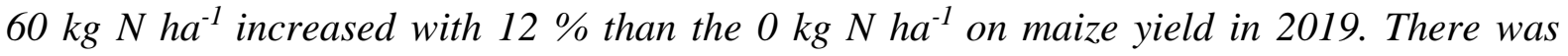
response to Zn fertilization on stover and grain yields. The interaction effects were significant on stover yield. The nitrogen rate of $60 \mathrm{~kg} \mathrm{~N} \mathrm{ha}^{-1}$ and the zinc rate of $2.5 \mathrm{~kg}$ were optimum for maize grain yield in Minna, both Oba Super 2 and Suwan-1-SR performed better in the study.
\end{abstract}

Keywords: Varietal, zinc, nitrogen, response, Minna

https://dx.doi.org/10.4314/jafs.v18i2.3

\section{INTRODUCTION}

Maize is one of the most important grains in Nigeria based on its economic value. It was introduced into Nigeria in the 10th century by the Portuguese (Oladejo and Adetunji, 2012). It is the third most important cereal crop worldwide after wheat and rice (Oladejo and Adetunji, 2012). It is referred to as the cereal of the future for its valuable nutritional facts in human diet (Enyisi et al., 2014). 
Maize has been in the diet of Nigerians for centuries. Africans consume maize as a starchybased food in a wide variety of porridges, pastes, grits, and beer (Eleweanyaet al., 2005). Green maize (fresh on the cob) is eaten parched, baked, roasted or boiled; playing an important role in filling the hunger gap after the dry season (Olaniyan, 2015). Apart from food, maize is also useful as medicines and as raw materials for industries (Afzal et al., 2009). There is high demand of maize yield due to high market demand for poultry feed. Maize is recognized as highly sensitive to $\mathrm{Zn}$ deficiency (Hossain et al, 2011). Zinc deficiency is a problem in food crops, causing decreased crop yields and nutritional quality (Cakmak, 2008).

Nitrogen is a vital plant nutrient and a major yield-determining factor required for maize production (Subedi and Ma, 2005). It is also a characteristic constituent element of proteins and also an integral component of many other compounds essential for plant growth processes including chlorophyll and many enzymes. Nitrogen and phosphorus are very essential for good vegetative growth and grain development in maize production.

Zinc is most crucial amongst the micronutrients that take part in plant growth and development due to its catalytic action in metabolism of almost all crops (George and Schmitt, 2002). Deficiency of $\mathrm{Zn}$ in soil causes deficiency in crops and altogether this has become problem all over the world with acute zinc deficiency ranges in arid to semi-arid regions of the world (Rashid and Ryan, 2004). Zn plays a major role in chlorophyll development and function, of which most important are the Zn-dependent activity of spp peptidase and the repair process of photo system II by turning over photo damaged D1 protein. (Hansch and Mendel, 2009). Deficiency of Zn reduces growth, tolerance to stress and chlorophy II synthesis (Kawachi, et al., 2009; Lee et al., 2010). The Zn that is available for plant uptake is in soil solution form, or is adsorbed in a labile form and thus, soil factors that affect its availability to plants are those which control the amount of $\mathrm{Zn}$ in soil solution and its sorption - desorption from / into the soil solution (Sharma et al., 2013). The objective of this study is to investigate the varietal response of maize to nitrogen and zinc fertilizer in Minna, Nigeria.

\section{MATERIALS AND METHODS}

\section{Study Site}

The study was conducted at the Teaching and Research Farm, Federal University of Technology Minna, located at latitude $9^{\circ} 31^{\prime} 860^{\prime \prime} \mathrm{N}$; longitude $6^{\circ} 27^{\prime} 244^{\prime \prime} \mathrm{E}$, its height is $207.8 \mathrm{~m}$ above sea level and is in the southern Guinea savanna of Nigeria. Climate of Minna is sub - humid, rainfall pattern is monomodal with the rainy season starting in April and ending in October. The physical features around Minna consist of gently undulating high plains developed on basement complex rocks made up of granites, migmatites, gneisses and schists. Inselbergs of Older Granites and low hills of schists rise conspicuously above the plains. Beneath the plains, bedrock is deeply weathered and constitutes the major soil parent material (saprolites) (Ojanuga 2006).

\section{Field experiments}

The experiments were conducted over two cropping seasons (2018 and 2019).

Journal of the Faculty of Agriculture and Veterinary Medicine, Imo State University Owerri website: www ajol.info; Attribution: Non-commercial CC BY-NC 


\section{Afolabi, S.G., Ewulo, B.S., Aiyelari, O.P., \\ Adeyemo, A.J.}

\section{Treatments and experimental design}

The experimental design was $4 \times 3 \times 2$ factorial experiment fitted to a randomized complete block design (RCBD) and with three replications. Treatment comprises of four levels of $\mathrm{N}$, $0,30,60,90 \mathrm{~kg} \mathrm{Nha}^{-1}$ and three levels of $\mathrm{Zn} 0,2.5,5, \mathrm{~kg} \mathrm{ha}^{-1}$ with two maize varieties (Oba Super 2 and Suwan-1-SR) resulting in twenty-four treatment combination, each plot size was $4 \mathrm{~m} \times 4 \mathrm{~m}$, the net plot was $9 \mathrm{~m}^{2}$.

\section{Agronomic practices}

The field was manually cleared and ridged at $75 \mathrm{~cm}$ apart. Maize variety, Oba super 2 was sowed (2 plants per stand) at $25 \mathrm{~cm}$ within the ridge, thinning was done to 1 plant per stand at 2 weeks after sowing (WAS). The N was supplied using NPK 15:15:15 fertilizer and urea and $\mathrm{Zn}$ was supplied using $\mathrm{ZnSO}_{4}$ to the required plots. The $\mathrm{N}$ was applied in split dose, half at 2 WAS using NPK 15:15:15 while the remaining half was applied at 6 WAS using urea. The $\mathrm{Zn}$ was mixed thoroughly with NPK; Fertilizers were applied by side banding.

\section{Soil sampling and analysis.}

Surface soil $(0-20 \mathrm{~cm})$ samples were collected from eight points along four diagonal transects before the start of the experiment; they were bulked together to form a composite sample to characterize the field. Soil samples collected were air-dried, crushed and sieved with a sieve of $2 \mathrm{~mm}$ sieve. The samples were subjected to analysis using standard methods. Soil $\mathrm{pH}$ was determined in a 1: 2.5 (soil:water) ratio and $0.1 \mathrm{M} \mathrm{CaCl}_{2}$ using a glass electrode pH meter. Particle size was determined by Bouyocous hydrometer method. Organic carbon was determined using Walkley-Black method (Nelson and Sommers, 1982). Determination of exchangeable bases was done by using ammonium acetate $\left(\mathrm{NH}_{4} \mathrm{OAc}\right)$ displacement method. $\mathrm{Na}^{+}$and $\mathrm{K}^{+}$in the extract were determined by flame photometric method, while $\mathrm{Ca}^{2+}$ and $\mathrm{Mg}^{2+}$ by Na-EDTA titrimetric method. Exchangeable acidity (EA) was by $\mathrm{KCl}$ extraction method, the extract was determined by titrimetric method as described by Udolet al., (2009). Available phosphorus extracted with the Bray $\mathrm{P} 1$ method and $\mathrm{P}$ in extract determined using spectrophotometer. Total nitrogen was determined by micro-Kjeldhal method (Bremner, 1982). Zinc was extracted using the dilute $\mathrm{HCl}$ and $\mathrm{Zn}$ in solution was determined by atomic absorption spectrophotometer.

\section{Growth and yield components analysis}

Maize plant height: Plant heights were recorded at 3, 6, 9 and 12 WAS by measuring from the soil level of maize plants to the tips of the tallest leaf using meter rule.

Number of leaves: The numbers of leaves were recorded at 3, 6, 9 and 12 WAS by visual counting of the leaves.

Shoot biomass: The maize was cut above ground level in the net plot $\left(9 \mathrm{~m}^{2}\right)$ at physiological maturity, dried and weighed using weighing balance and the weight was recorded

Cob length: The length of the harvested cobs was measured using meter rule.

Maize grain yield: Maize yield was carried out by harvesting maize ears in the net plot (8 $\mathrm{m}^{2}$ ). These were shelled, air-dried and weighed.

Journal of the Faculty of Agriculture and Veterinary Medicine, Imo State University Owerri website: www ajol.info; Attribution: Non-commercial CC BY-NC 
Statistical analysis: Analysis of variance (ANOVA) was used to evaluate the treatment effects on data collected. Means separation was carried out where significant differences were observed using Duncan Multiple Range Test (DMRT) at $5 \%$ level of probability using Statistical Analysis System (SAS).

\section{RESULTS AND DISCUSSION}

\section{Some Physical and Chemical Properties of the Soil Prior to Planting}

The results of the physical and chemical properties of the soil prior to land preparation in 2018 are shown in Table 1 . The soil texture was sandy loam, $\mathrm{pH}$ was slightly acidic in $\mathrm{H}_{2} \mathrm{O}$, low in organic carbon, available $\mathrm{P}$, total $\mathrm{N}$ and the extractable $\mathrm{Zn}$ (Esu, 1991). The $\mathrm{pH}$ was slightly acidic which was suitable for plant growth as most plant nutrients are available for plant uptake at pH 5.5-6.5 (Brady and Weil, 2002). The low organic carbon content of the soil might be partly attributed to the rapid organic matter mineralization. The extractable $\mathrm{Zn}$ was low (Esu, 1991) and below the critical range of $2.0 \mathrm{mg} \mathrm{kg}^{-1}$ for extractable $\mathrm{Zn}$ established by Sims and Johnson (1991). And also, below the critical level of $2.20 \mathrm{mg} \mathrm{kg}^{-1}$ established for some savanna soils by Yusuf et al (2005).

\section{Effect of Nitrogen, Zinc and Variety on the Growth of Maize in 2018 and 2019 Seasons}

The main effect of $\mathrm{N}, \mathrm{Zn}$ and variety on the plant height of maize were significant in 2018 and 2019 seasons. At 3 WAS in 2018, 60 and $90 \mathrm{~kg} \mathrm{~N} \mathrm{ha}^{-1}$ produced the tallest plant 43.69 and $44.37 \mathrm{~cm}$ which was only significantly different from that of $0 \mathrm{~kg} \mathrm{~N} \mathrm{ha}^{-1}$. Application of $\mathrm{N}$ produced the taller plant at 6 WAS which was significantly different from others rates. The 30 and $60 \mathrm{~kg} \mathrm{~N} \mathrm{ha}^{-1}$ where statistically similar $153.93 \mathrm{~cm}$ and $158.29 \mathrm{~cm}$ but significantly different from the $0 \mathrm{~kg} \mathrm{~N} \mathrm{ha}^{-1}(126.49 \mathrm{~cm})$ at $6 \mathrm{WAS}$. The $60(181.42 \mathrm{~cm})$ and $90(190.98 \mathrm{~cm})$ $\mathrm{kg} \mathrm{N}$ ha ${ }^{-1}$ produced the taller plant which were significantly different from the $0 \mathrm{~kg} \mathrm{~N} \mathrm{ha}^{-1}$. Similar result wasobserved at 12 WAS (Table 2). Application of N produced taller plants at 3, 6, 9 and 12 WAS in 2019 which were significantly taller than plants without $\mathrm{N}$ fertilization (Table 2). The maize effect of $\mathrm{Zn}$ fertilization on the height of maize was not significant at all the growth stages of maize in 2018. Application of $\mathrm{Zn}$ produced significantly taller plants than those without Zn application at 3 and 9 WAS in 2019, but at 6 WAS, plants with $5 \mathrm{~kg}$ Zn $\mathrm{ha}^{-1}$ produced the tallest plant with a height of $119.22 \mathrm{~cm}$ which was only significantly from the treatment with $0 \mathrm{~kg} \mathrm{Zn} \mathrm{ha}{ }^{-1}$. There was significantly different from the variety. The Suwan-1-SR produced tallest plant which was significantly different from Oba Super 2 at all stages of the growth of plant in both 2018 and 2019 except at 12 WAS in 2018 which was significantly similar to each other.

The interaction effect of $\mathrm{N}$ and $\mathrm{Zn}$ on growth of maize plant was only significant at 9 WAS in 2018 season. The application of $\mathrm{Zn}$ at $5 \mathrm{~kg} \mathrm{Zn} \mathrm{ha}{ }^{-1}$ and 60 and $90 \mathrm{~kg} \mathrm{~N}^{-1}$ fertilization produced the tallest maize plants (Table 3). Plants with the shortest height of $144.85 \mathrm{~cm}$ was obtained with application of $0 \mathrm{~kg} \mathrm{Zn} \mathrm{ha}^{-1}$ and $0 \mathrm{~kg} \mathrm{~N}^{-1}$ which was not significantly different from those of 2.5 and $5 \mathrm{~kg} \mathrm{Zn} \mathrm{ha}^{-1}+0 \mathrm{~kg} \mathrm{~N} \mathrm{ha}^{-1}$ and $30 \mathrm{~kg} \mathrm{~N} \mathrm{ha}^{-1}+5 \mathrm{~kg} \mathrm{Zn} \mathrm{ha}^{-1}$ in 2018. There was interaction effect between the $\mathrm{N}$ and variety at 3 and 6 WAS in 2018 (Table 4). At 3 WAS application of $30 \mathrm{~kg} \mathrm{~N} \mathrm{ha}^{-1}$ with Suwan-1-SR produced the taller plant which was significantly different from other combinations except the $90 \mathrm{~kg} \mathrm{~N} \mathrm{ha}^{-1}$ with Oba Super 2 Journal of the Faculty of Agriculture and Veterinary Medicine, Imo State University Owerri website: www ajol.info; Attribution: Non-commercial CC BY-NC 
and $60 \mathrm{~kg} \mathrm{~N}^{-1}$ with Suwan-1-SR. At 6 WAS Application of $\mathrm{N}$ irrespective of seasons, the rate and variety were significant taller than $0 \mathrm{~kg} \mathrm{~N} \mathrm{ha}^{-1}$ with either of the variety except the 90 $\mathrm{kg} \mathrm{N} \mathrm{ha}^{-1}$ with Oba Super 2 with $148.59 \mathrm{~cm}$.

The main effect of $\mathrm{N}, \mathrm{Zn}$ and variety on the number of maize leaves in 2018 and 2019 seasons was shown in Table 5 . The $30 \mathrm{~kg} \mathrm{~N}^{-1}$ produced the highest number of leaves which was significantly different from others at 6 WAS in 2018, similar results was observed at 9 WAS but it is similar to application of $60 \mathrm{~kg} \mathrm{~N} \mathrm{ha}^{-1}$. There were no significantly different at 3 and 9 WAS in 2018. The N produced the highest leaves at 3, 6 and 12 WAS which were significantly different from the $0 \mathrm{~kg} \mathrm{~N} \mathrm{ha}{ }^{-1}$ in 2019 (Table 5). The maize effect of $\mathrm{Zn}$ fertilization on the number of maize leaves was not significant at all the growth stage of maize in both 2018 and 2019 seasons. The Suwan-1-SRwas significantly different from Oba Super 2 at 3 WAS in 2018 and 3, 6 WAS in 2019. There were no significantly different on number of leaves at 6,9 and 12 in 2018 and 9 and 12 WAS in 2019.

The interaction effects of both $\mathrm{N}, \mathrm{Zn}$ and variety on number of leaves was not significant in both years. Zinc has lesser role in the vegetative growth of plant while its requirement is more during reproductive phase in comparison to vegetative growth stage (Dileep, 2013). The same was observed during this experiment. Zinc application improves the growth because zinc is involved directly and indirectly as co-enzyme in photosynthetic process which provide substrate for growth and development (Vallee and Falchuk, 1998). It produced more tillers in similar crop like rice (Moussavi-Nik et al., 1997).

\section{Effect of Nitrogen, Zinc and Variety on the Yield of Maize in 2018 and 2019 Seasons}

The main effects of N, Zn and variety on the yields of maize in 2018 and 2019 seasons are shown in Table 6 . The main effects of $\mathrm{N}$ and $\mathrm{Zn}$ on grain yield and stover yield of maize were significant in both seasons while cob weight was significant only in 2019 season. The treatment $60 \mathrm{~kg} \mathrm{~N} \mathrm{ha}^{-1}$ had significantly higher yield $\left(27873.7 \mathrm{~kg} \mathrm{ha}^{-1}\right)$ than others but similar to $90 \mathrm{~kg} \mathrm{~N} \mathrm{ha}^{-1}\left(2512.4 \mathrm{~kg} \mathrm{ha}^{-1}\right)$. The $90 \mathrm{~kg} \mathrm{~N} \mathrm{ha}^{-1}$ was statistically similar to $30 \mathrm{~kg} \mathrm{~N} \mathrm{ha}^{-1}$

(2308.4 $\mathrm{kg} \mathrm{ha}^{-1}$ ) Application of $60 \mathrm{~kg} \mathrm{~N} \mathrm{ha}^{-1}$ increased with $12 \%$ than the $0 \mathrm{~kg} \mathrm{~N} \mathrm{ha}^{-1}$ on maize yield in 2019. There was similarity between the $30 \mathrm{~kg} \mathrm{~N} \mathrm{ha}^{-1}$ and $90 \mathrm{~kg} \mathrm{~N} \mathrm{ha}^{-1}$ on grain yield of maize. There was significantly different on the stover yield of maize. The highest rate of application produced significantly higher stover than others both season but similar to that of $60 \mathrm{~kg} \mathrm{~N} \mathrm{ha}^{-1}$. In 2019 maize cobs weight was significantly higher with the $90 \mathrm{~kg} \mathrm{~N} \mathrm{ha}$ ${ }^{1}$ than the $30 \mathrm{~kg} \mathrm{~N} \mathrm{ha}^{-1}$ and $0 \mathrm{~kg} \mathrm{~N} \mathrm{ha}^{-1}$. There were no significant differences on cob length and 1000 grain weight in respect to $\mathrm{N}$ in both seasons.

Main effects of $\mathrm{Zn}$ on both stover and grain yields were only significant in both seasons while the cob weight was significant in 2019. There was response to $\mathrm{Zn}$ fertilization by both yields with the $0 \mathrm{~kg} \mathrm{Zn} \mathrm{ha}^{-1}$ treatment providing stover and yields of 2518.8 and $2007.5 \mathrm{~kg} \mathrm{ha}^{-1}$ respectively in 2018 and 2477.71 and $1402.5 \mathrm{~kg} \mathrm{ha}^{-1}$ in 2019 which were significantly different from that of those with $\mathrm{Zn}$ fertilization. The $5 \mathrm{~kg} \mathrm{Zn} \mathrm{ha}{ }^{-1}$ produced higher cob weight than others in 2019. There was no significant difference on the variety used except in 2019 where the cob weight produced the heaviest weight with application of $5 \mathrm{~kg} \mathrm{Zn} \mathrm{ha}^{-1}$.

Journal of the Faculty of Agriculture and Veterinary Medicine, Imo State University Owerri website: www ajol.info; Attribution: Non-commercial CC BY-NC 
There were interaction effects between the $\mathrm{N}$ and $\mathrm{Zn}, \mathrm{N}$ and V, N, Zn and V on stover yield of maize in 2019.

The interaction effects of nitrogen and zinc on stover yield in 2019 season in Minna was shown in Table 7. Application of $90 \mathrm{~kg} \mathrm{~N} \mathrm{ha}^{-1}$ and $5 \mathrm{~kg} \mathrm{Zn} \mathrm{ha}{ }^{-1}$ produced the heaviest weight (4083.3 $\left.\mathrm{kg} \mathrm{ha}^{-1}\right)$ which was significantly different from other treatment combinations. The treatment combination of $90 \mathrm{~kg} \mathrm{~N} \mathrm{ha}{ }^{-1}+2.5 \mathrm{~kg} \mathrm{Zn} \mathrm{ha}^{-1}$ were similar to $60 \mathrm{~kg} \mathrm{~N} \mathrm{ha}{ }^{-1}+5 \mathrm{~kg}$ $\mathrm{Zn} \mathrm{ha}^{-1}$ and $30 \mathrm{~kg} \mathrm{~N} \mathrm{ha}^{-1}+2.5 \mathrm{~kg} \mathrm{Zn} \mathrm{ha}^{-1}$. The interaction effects of nitrogen and variety in 2019 was shown in Table 8 . Application of $90 \mathrm{~kg} \mathrm{~N}$ ha $^{-1}$ with Suwan-1-SR produced the stover yield of $3455.80 \mathrm{~kg} \mathrm{ha}^{-1}$ which was significantly higher than $0 \mathrm{~kg} \mathrm{~N}^{-1}$ with either Oba Super 2 or Suwan-1-SR. The interaction effects of nitrogen, zinc and variety on stover yield in 2019 in Minna. The $90 \mathrm{~kg} \mathrm{~N} \mathrm{ha}^{-1}+5 \mathrm{~kg} \mathrm{Zn} \mathrm{ha}^{-1}$ with Suwan-1-SR produced significantly higher stover yield than other treatment combinations but similar to the $30 \mathrm{~kg} \mathrm{~N}$ $\mathrm{ha}^{-1}+2.5 \mathrm{~kg} \mathrm{Zn} \mathrm{ha}^{-1}$ with Suwan-1-SR (Table 9). Grain yield increased with the application of $\mathrm{Zn}$ as reported by Morshedi and Farahbakhsh (2010) and Bashir et al., (2012). They also attributed the superior yield attributes with the application of $\mathrm{ZnSO}_{4} \mathrm{ha}^{-1}$ and more translocation of photosynthate towards sink. The increase in these parameters might be due to involvement of zinc in various enzymatic processes which helps in catalyzing reaction for growth finally leading to development of more yield attributing character.

Sharma et al., (1992) reported that the seed yield of maize increased by $11.4 \%$ up to Zn levels from 0 to $9 \mathrm{~kg} \mathrm{Zn/ha.} \mathrm{Similar} \mathrm{result} \mathrm{was} \mathrm{also} \mathrm{reported} \mathrm{by} \mathrm{Cakmaket} \mathrm{al.} \mathrm{(1997)} \mathrm{with} \mathrm{other}$ crops like rye, triticale, bread and durum wheats increase due to application of $\mathrm{Zn}$.

There was clear evidence that $\mathrm{N}$ nutrition was a major constraint to maize production (Yusuf et al., 2009). Lawal et al., (2013) reported that application of $\mathrm{N}$ fertilizer increased maize yield in the Guinea savanna. Adeboyeet al., (2009) also reported that $90 \mathrm{~kg} \mathrm{~N}^{-1}$ to be optimum for maize in the area. In the West African savannas, 60 to $120 \mathrm{~kg} \mathrm{~N} \mathrm{ha}^{-1}$ had been recommended by Carsky and Iwuafor (1999). Onasanyaet al., (2009) attributed an increase in the growth of the maize plant to $\mathrm{N}$ fertilizer application.

\section{CONCLUSION}

The result of this study established the response of maize to inorganic nitrogen and zinc fertilizer application. Nitrogen and zinc application to maize is therefore required for optimum yield. $90 \mathrm{~kg} \mathrm{~N} \mathrm{ha}^{-1}$ improved the growth in both 2018 and 2019 seasons. Suwan-1SR performed better in term of growth and $5 \mathrm{~kg} \mathrm{Zn} \mathrm{ha}^{-1}$ also increased the plant height in 2019. In addition, the nitrogen rate of $60 \mathrm{~kg} \mathrm{~N} \mathrm{ha}^{-1}$ and the zinc rate of $2.5 \mathrm{~kg}$ were optimum for maize grain yield in Minna. Both Oba Super 2 and Suwan-1-SR performed better in the study.

Journal of the Faculty of Agriculture and Veterinary Medicine, Imo State University Owerri website: www ajol.info; Attribution: Non-commercial CC BY-NC 


\section{REFERENCES}

Adeboye, M.K.A., Osunde, A.O., Tsado, P.A., Odofin, J.A., Bala, A. \& Adeyemi, R.A. (2009). Response of maize grain yields to rates and split application of nitrogen and NPK combinations in the southern Guinea savanna of Nigeria. Journal of Agriculture and Agricultural Technology. 2(1): 108-118.

Afzal, M., Nasir, Z., Bashir M.H. \& Khan, B.S. (2009). Analysis of list plant resistance in some genotypes of maize against Chilopartellus (Swinhoe) (Pyralidae: Lepidoptera). Pakistan Journal of Botany. 41:421428

Bashir, F., Maqsood, M., Sarwar, N., Ali, H., Mubeen, K., Muhammad \& Shehzad, A. (2012) Effect of foliar application of zinc on yield and radiation use efficiency (RUE) of maize (Zea mays L.) under reduced irrigation conditions. Asian Journal of Pharmaceutical and Biological Research 2(1)33-39.

Brady, N.C. \& Weil, R. (2010). The nature and properties of soils. 3rd edition, person education, Inc., Upper Saddle River, New Jersey 07456, Pp 960.

Bremner, J. M. (1982). Inorganic nitrogen. In page A. L, Miller, R. H \& Keeney, D. R. (eds). Methods of soil analysis. Part II $2^{\text {nd }}$ edition. America Society of Agronomy. Madison Wiscosin.

Cakmak, I., H. Ekij, A. Yilmaz, B. Torun, N. Koleli, I. Gultekin, A. Alkan \& S. Eker. (1997). Differential response of rye, triticale, bread and durum wheats to zinc deficiency in $\begin{array}{lllllll}\text { calcareous soils. Plant and Soil 188(1): } & 1 & -10 .\end{array}$ https://doi.org/10.1023/A:1004247911381

Cakmak, I. (2008). Enrichment of cereal grains with zinc: Agronomic or genetic biofortification? Plant and Soil, 302, 1-17. https://doi.org/10.1007/s11104-007-9466$\underline{3}$

Carsky, R.J. \& Iwuafor, E.N.O. (1999). Contribution of soil fertility research and maintenance to improved maize production and productivity in sub-Saharan Africa. Pp. 3-20. In, Badu-Apraku, B., M.A.B. Fakorede, M. Ouedraogo and P.M. Quin (eds). Strategyfor Sustainable Maize Production in West and Central Africa. Proceedings of a Regional Maize Workshop, IITA-Cotonou, Benin Republic, 2125 April, 1997. WECAMAN/IITA.

Dileep, K. (2013). Agronomic biofortification through zinc nutrition in maize (Zea mays) wheat (Triticum aestivam) cropping system. A PhD. Thesis Indian Agricultural Research Institute New Delhi, India. Page 1-130.

Eleweanya, N. P., Uguru, M. I., Enebong, E. E. \&Okoche, P. I. (2005). Correlation and path coefficient analysis of grain yield and related characteristics in maize under Umudike conditions of South East Nigeria. Agro-science Journal of Tropical Agriculture, Food, Environment and Extension 1: 24 - 28.

Enyisi, I.S., Umoh, V.J., Whong, C.M.Z., Abdullahi, I.O. \& Alabi, O. (2014). Chemical and nutritional value of maize and maize products obtained from selected markets in

Journal of the Faculty of Agriculture and Veterinary Medicine, Imo State University Owerri website: www ajol.info; Attribution: Non-commercial CC BY-NC 
Kaduna State, Nigeria. African Journal of Food Science and Technology, 5(4), 100104.

Esu, I.E. (1991) Detailed soil survey of NIHORT Farm at Bunkure, Kano State, Nigeria. Institute for Agricultural Research, Ahmadu Bello University, Zaria, Nigeria. 72 pp.

George, R. \& M. Schmitt. (2002). Zinc for crop production. Regents of the University of Minnesota.

Hansch, R. \& Mendel, R. R. (2009). Physiological functions of mineral micronutrients (Cu, Zn, Mn, Fe, Ni, Mo, B, Cl). Current Opinion in Plant Biology, 12: 259 - 266. https://doi.org/10.1016/j.pbi.2009.05.006

Hossain, M. A., Ahiruddin, M. J. \& Khatun, F. (2011). Response of maize varieties to zinc fertilization. Bangladesh Journal of Agricultural Research. 36(3): 437-447. https://doi.org/10.3329/bjar.v36i3.9272

Kawachi, M., Kobac, Y., Mori, H., Tomioka, R., Lee, Y. \& Maeshima, M. (2009). A mutant strain Arabidopsis thaliamathat lacks vacuolar membrane zinc transporter. MTPI revealed the latent tolerance to excessive zinc. Plant cell physiology, 50: 1156 1170. https://doi.org/10.1093/pcp/pcp067

Lawal, B.A, Adeboye, M.K.A., Usman, A., Afolabi, S.G. \& Adekanmbi, A.A. (2015). Rotation effect of Aeschynomenehistrix on soil carbon and nitrogen and maize grain yield at Minna in the southern Guinea savanna of Nigeria. Journal of Agriculture and Agricultural Technology, 6(1): 1-9.

Lee, S., Kim, S.A., Lee, J. \& Guerinot, M.I. (2010). Zinc deficiency - inducible os ZIP8 encodes a plasma membrane - localized zinc transporter in rice. Molecular Cells, 29: 551 - 558. https://doi.org/10.1007/s10059-010-0069-0

Morshedi, A. \& Farahbakhsh, H. (2010) Effects of potassium and zinc on grain protein contents and yield of two wheat genotypes under soil and water salinity and alkalinity stresses. Plant Ecophysiology 2:67-72.

Moussavi-Nik, M., Rengel, Z., Pearson, J.N. \& Hollamby, G. (1997). Dynamics of nutrient remobilization from seed of wheat genotypes during imbibition, germination and early seedling growth. Plant and Soil. 197: 271-280. https://doi.org/10.1023/A:1004227400287

Nelson, D. W. \& Sommers, L. S. (1982). Total carbon, organic carbon and organic matter. In Page, A.L. et al., Agronomy Monogram 9 ( $2^{\text {nd }}$ edition). ASA and SSSA. Madison, Wisconsin. P. $403-430$.

Ojanuga, A.G. (2006). Agroecological Zones of Nigeria Manual. FAO/NSPFS, Federal Ministry of Agriculture and Rural Development, Abuja, Nigeria, 124 pp.

Oladejo, J. A. \& Adetunji, M. O. (2012). Economic analysis of maize (zea mays 1.) production in Oyo State of Nigeria. Agricultural Science Research Journals. 2(2): 77-83.

Journal of the Faculty of Agriculture and Veterinary Medicine, Imo State University Owerri website: www ajol.info; Attribution: Non-commercial CC BY-NC 
Olaniyan, A. B. (2015). Maize: Panacea for hunger in Nigeria. African Journal of Plant Science. 9 (3), 155 -174. https://doi.org/10.5897/AJPS2014.1203

Onasanya, R.O., Aiyelari, O.P., Onasanya, A., Oikeh, S., Nwilene, F.E., \& Oyelakin, O.O. (2009). Growth and Yield Response of Maize (Zea mays L.) to Different Rates of Nitrogen and Phosphorus Fertilizers in Southern Nigeria. World Journal of Agricultural Science. 5 (4): 400-407. https://doi.org/10.3923/ijar.2009.193.203

Rashid, A. \& J. Ryan. (2004). Micronutrient constraints to crop production in soils with Mediterranean-type characteristics: A review. Journal of Plant Nutrition. 27:959-9. https://doi.org/10.1081/PLN-120037530

Sharma, A., Patri, B., Shankhdhar, D. \&Shankhdhar, S.C. (2013). Zinc - An indispensable micronutrient. Physiology and Molecular Biology of Plants, 19(1): 11-20. https://doi.org/10.1007/s12298-012-0139-1

Sims, J.T. \& Johnson, G.V. (1991). Micronutrients Soil Tests. Second Edition. In Mortvedt, J.J., Cox, F.R., Shirman, L.M., Welch, R.M. (Eds). Micronutrients in Agriculure. Soil Science Society of America Inc., Madison, Wisconsin, USA. https://doi.org/10.2136/sssabookser4.2ed.c12

Sharma, S.K., B.N. Swami \& R.K. Singh. (1992). Relative responsiveness of maize (Zea mays) varieties to zinc. Indian Journal of Agronomy. 37 (2): 361-362.

Subedi, K.D. \& Ma, B.C. (2015). Ear position, leaf area and contribution of individual leaves to grain yield in conventional and leafy maize hybrids. Crop Science. 45: 2246-2257. https://doi.org/10.2135/cropsci2004.0653

Vallee, B.L. \& Falchuk, K.H. (1998). The biochemical basis of zinc physiology. Physiological Reviews. 73(1):79-118. https://doi.org/10.1152/physrev.1993.73.1.79

Udo, E. J., Ibia, T. O., Ogunwale, J. A., Ano, A. O. \&Esu, I. E. 2009. Manual of soil, plant and water analysis, Sibon books LTD, flat 15, blk. 6, fourth avenue Festac, Lagos.

Yusuf, A.A., Abdu, N., Chude, V.O., Yusuf, H.A. \& Pam, S.G. (2005). Response of maize (Zea mays L.) to zinc fertilization in relation to mehlich extractable zinc in northern Nigeria. Nigerian Journal of Soil Research. 6, 32-41. https://doi.org/10.4314/njser.v6i1.28393

Yusuf, A.A., Iwuafor, E.N.O. Abaidoo, R.C., Olufajo, O.O. \&Sanginga, N (2009). Grain legume rotation benefits to maize in the northern Guinea savanna of Nigeria: Fixednitrogen versus other rotation effects. Nutrient Cycling in Agroecosystem. 84: 129139. https://doi.org/10.1007/s10705-008-9232-9 
Journal of Agriculture and Food Sciences

Afolabi, S.G., Ewulo, B.S., Aiyelari, O.P., 48

Volume 18, Number 2, October 2020, pp 39 - 53.

\section{APPENDIX}

Table 1: Some soil physical and chemical properties before sowing

\begin{tabular}{lc}
\hline Parameters & Values \\
\hline Sand & 768 \\
Silt $\left(\mathrm{g} \mathrm{kg}^{-1}\right)$ & 79 \\
Clay $\left(\mathrm{g} \mathrm{kg}^{-1}\right)$ & 153 \\
Textural class & Sandy loam \\
Soil pH $\left(\mathrm{H}_{2} \mathrm{O}\right)$ & 5.22 \\
Soil pH $\left(\mathrm{CaCl}_{2}\right)$ & 4.27 \\
Total nitrogen $\left(\mathrm{g} \mathrm{kg}^{-1}\right)$ & 0.10 \\
Organic carbon $\left(\mathrm{g} \mathrm{kg}^{-1}\right)$ & 3.56 \\
Available phosphorous $\left(\mathrm{mg} \mathrm{kg}^{-1}\right)$ & 6 \\
Exchangeable bases $\left(\mathrm{cmol} \mathrm{kg}^{-1}\right)$ & \\
Ca & 1.68 \\
Mg & 0.03 \\
$\mathrm{~K}$ & 0.31 \\
Na & 0.08 \\
Exchangeable acidity $\left(\mathrm{cmol} \mathrm{kg}^{-1}\right)$ & 0.12 \\
ECEC & 2.22 \\
Zinc (mg kg & 1.34 \\
\hline
\end{tabular}

Means for same column and factor followed by the same letter are not significantly different at $5 \%$ level of probability.

Table 2: Effects of nitrogen zinc and variety on plant height of maize in 2018 and 2019

\begin{tabular}{llcllllll}
\hline & \multicolumn{3}{c}{2018} & \multicolumn{5}{c}{2019} \\
& 3WAS & 6 WAS & 9 WAS & 12 WAS & 3 WAS & 6 WAS & 9 WAS & 12 WAS \\
\hline Nitrogen (N) & & & & & & & & \\
0 & $40.14 \mathrm{~b}$ & $126.49 \mathrm{c}$ & $148.49 \mathrm{c}$ & $164.77 \mathrm{~b}$ & $38.37 \mathrm{~b}$ & $81.45 \mathrm{~b}$ & $181.94 \mathrm{~b}$ & $209.49 \mathrm{~b}$ \\
30 & $44.37 \mathrm{a}$ & $153.93 \mathrm{~b}$ & $172.64 \mathrm{~b}$ & $200.82 \mathrm{a}$ & $99.33 \mathrm{a}$ & $123.67 \mathrm{a}$ & $202.73 \mathrm{a}$ & $226.04 \mathrm{ab}$ \\
60 & $41.14 \mathrm{ab}$ & $158.29 \mathrm{~b}$ & $181.42 \mathrm{ab}$ & $194.27 \mathrm{a}$ & $103.51 \mathrm{a}$ & $124.99 \mathrm{a}$ & $209.84 \mathrm{a}$ & $230.43 \mathrm{a}$ \\
90 & $44.37 \mathrm{a}$ & $177.70 \mathrm{a}$ & $190.98 \mathrm{a}$ & $172.57 \mathrm{~b}$ & $104.92 \mathrm{a}$ & $122.21 \mathrm{a}$ & $214.17 \mathrm{a}$ & $242.79 \mathrm{a}$ \\
SE \pm & 1.25 & 6.19 & 4.85 & 6.00 & 4.36 & 5.45 & 6.89 & 6.65 \\
Zinc $(\mathrm{Z})$ & & & & & & & & \\
\hline
\end{tabular}

Journal of the Faculty of Agriculture and Veterinary Medicine, Imo State University Owerri website: www ajol.info; Attribution: Non-commercial CC BY-NC 
Volume 18, Number 2, October 2020, pp 39 - 53.

\begin{tabular}{|c|c|c|c|c|c|c|c|c|}
\hline 0 & $41.67 \mathrm{a}$ & $151.51 \mathrm{a}$ & $172.44 \mathrm{a}$ & $177.85 \mathrm{a}$ & $80.54 b$ & $109.10 \mathrm{~b}$ & $199.28 b$ & $222.55 a$ \\
\hline 2.5 & $42.06 \mathrm{a}$ & $157.23 \mathrm{a}$ & $174.48 \mathrm{a}$ & $186.85 \mathrm{a}$ & $91.71 \mathrm{a}$ & $110.92 \mathrm{ab}$ & $206.30 \mathrm{a}$ & $233.81 \mathrm{a}$ \\
\hline 5 & $43.27 \mathrm{a}$ & $153.57 \mathrm{a}$ & $173.23 a$ & $185.49 \mathrm{a}$ & $99.54 \mathrm{a}$ & $119.22 \mathrm{a}$ & $200.94 a$ & $225.20 \mathrm{a}$ \\
\hline SE \pm & 1.15 & 6.57 & 5.34 & 6.10 & 4.93 & 5.99 & 6.24 & 6.08 \\
\hline \multicolumn{9}{|l|}{ Variety (V) } \\
\hline Oba Super 2 & $39.36 b$ & $147.49 b$ & $163.79 b$ & $178.04 \mathrm{a}$ & $80.12 b$ & $96.23 b$ & $192.12 b$ & $217.57 b$ \\
\hline Suwan-1-SR & $45.31 \mathrm{a}$ & $160.71 \mathrm{a}$ & $182.98 \mathrm{a}$ & $188.54 \mathrm{a}$ & $106.94 a$ & $129.93 \mathrm{a}$ & $212.22 \mathrm{a}$ & $236.81 \mathrm{a}$ \\
\hline SE \pm & 0.79 & 5.29 & 4.03 & 4.92 & 3.39 & 4.03 & 4.99 & 4.79 \\
\hline \multicolumn{9}{|l|}{ Interraction } \\
\hline $\mathrm{NxZ}$ & NS & NS & $*$ & NS & NS & NS & NS & NS \\
\hline $\mathrm{NxV}$ & $*$ & $*$ & NS & NS & NS & NS & NS & NS \\
\hline $\mathrm{ZxV}$ & NS & NS & NS & NS & NS & NS & NS & NS \\
\hline $\mathrm{NxZxV}$ & $\mathrm{NS}$ & NS & NS & $\mathrm{NS}$ & NS & NS & $\mathrm{NS}$ & $\mathrm{NS}$ \\
\hline
\end{tabular}

WAS- Weeks After Sowing; * Significant at $5 \%$ level of probability, NS- Not Significant

Table 3: Interaction effects of nitrogen and zinc on plant height in 2018 at 9 weeks after sowing season in Minna

\begin{tabular}{ccc}
\hline & Zinc & Plant height $(\mathrm{cm})$ \\
\hline 0 & 0 & $144.85 \mathrm{e}$ \\
0 & 2.5 & $154.30 \mathrm{cde}$ \\
0 & 5 & $146.33 \mathrm{de}$ \\
30 & 0 & $175.82 \mathrm{abc}$ \\
30 & 2.5 & $191.17 \mathrm{ab}$ \\
30 & 5 & $169.51 \mathrm{bcde}$ \\
60 & 0 & $170.62 \mathrm{abcde}$ \\
60 & 2.5 & $198.48 \mathrm{a}$ \\
60 & 5 & $193.77 \mathrm{ab}$ \\
90 & 0 & $183.30 \mathrm{ab}$ \\
90 & 2.5 & $193.77 \mathrm{ab}$ \\
90 & 5 & $179.87 \mathrm{abc}$ \\
\hline
\end{tabular}

Means in a column followed by the same letters are not significantly different at $5 \%$ level of probability. 
Volume 18, Number 2, October 2020, pp $39-53$.

Table 4: Interaction effects of nitrogen and variety on plant height at 3 and 6 weeks after sowing in Minna 2018

\begin{tabular}{ccccc}
\hline & \multicolumn{2}{c}{3 weeks after sowing } & \multicolumn{2}{c}{6 weeks after sowing } \\
\hline Nitrogen & Oba super 2 & Suwan-1-SR & Oba super 2 & Suwan-1-SR \\
\hline 0 & $37.20 \mathrm{~d}$ & $38.62 \mathrm{~cd}$ & $122.31 \mathrm{~d}$ & $130.66 \mathrm{dc}$ \\
30 & $40.12 \mathrm{~cd}$ & $45.79 \mathrm{ab}$ & $168.45 \mathrm{ab}$ & $186.96 \mathrm{a}$ \\
60 & $40.10 \mathrm{~cd}$ & $48.64 \mathrm{a}$ & $158.25 \mathrm{abc}$ & $158.32 \mathrm{abc}$ \\
90 & $45.07 \mathrm{ab}$ & $42.44 \mathrm{bc}$ & $148.59 \mathrm{bcd}$ & $160.62 \mathrm{ab}$ \\
\hline
\end{tabular}

WAS- weeks after sowing

Means in a column or row followed by the same letters are not significantly different at $5 \%$ level of probability.

Table 5: Effects of nitrogen zinc and variety on number of leaves of maize in 2018 and 2019

\begin{tabular}{|c|c|c|c|c|c|c|c|c|}
\hline & \multicolumn{4}{|c|}{2018} & \multicolumn{4}{|c|}{2019} \\
\hline & 3 & 6 & 9 & 12 & 3 & 6 & 9 & 12 \\
\hline 0 & $6.67 a$ & $10.21 \mathrm{c}$ & $11.09 \mathrm{c}$ & $11.86 \mathrm{a}$ & $6.71 b$ & $8.61 b$ & $12.13 \mathrm{a}$ & $12.82 b$ \\
\hline 30 & $6.81 \mathrm{a}$ & $12.16 \mathrm{a}$ & $12.25 \mathrm{a}$ & $12.67 \mathrm{a}$ & $8.93 a$ & $10.50 \mathrm{a}$ & $12.91 \mathrm{a}$ & $13.23 \mathrm{ab}$ \\
\hline 60 & $6.76 a$ & $11.18 b$ & $11.84 \mathrm{ab}$ & $12.25 \mathrm{a}$ & $9.32 \mathrm{a}$ & $10.86 a$ & $12.34 \mathrm{a}$ & $14.22 \mathrm{a}$ \\
\hline 90 & $6.65 a$ & $10.60 \mathrm{bc}$ & $11.33 b c$ & $11.86 \mathrm{a}$ & $8.93 a$ & $10.91 \mathrm{a}$ & $12.13 \mathrm{a}$ & $14.25 \mathrm{a}$ \\
\hline $\begin{array}{l}\text { SE } \pm \\
\text { Zinc }(Z)\end{array}$ & 0.22 & 0.29 & 0.22 & 0.25 & 0.30 & 0.33 & 0.27 & 0.31 \\
\hline 0 & $6.78 \mathrm{a}$ & $11.00 \mathrm{a}$ & $11.64 \mathrm{a}$ & $12.28 \mathrm{a}$ & $8.22 \mathrm{a}$ & $10.31 \mathrm{a}$ & $12.34 \mathrm{a}$ & $13.54 \mathrm{a}$ \\
\hline 2.5 & $6.63 a$ & $11.37 \mathrm{a}$ & $11.81 \mathrm{a}$ & $12.32 \mathrm{a}$ & $8.43 a$ & $10.32 \mathrm{a}$ & $12.34 \mathrm{a}$ & $13.81 \mathrm{a}$ \\
\hline 5 & $6.74 a$ & $10.75 a$ & $11.42 \mathrm{a}$ & $11.98 \mathrm{a}$ & $8.71 \mathrm{a}$ & $10.52 \mathrm{a}$ & $12.64 \mathrm{a}$ & $14.00 \mathrm{a}$ \\
\hline $\begin{array}{l}\text { SE } \pm \\
\text { Variety(V) }\end{array}$ & 0.14 & 0.29 & 0.20 & 0.15 & 0.33 & 0.34 & 0.24 & 0.35 \\
\hline Oba Super 2 & $6.41 b$ & $11.26 \mathrm{a}$ & $11.72 \mathrm{a}$ & $12.31 \mathrm{a}$ & $7.86 \mathrm{~b}$ & $9.39 b$ & $12.33 \mathrm{a}$ & $13.62 \mathrm{a}$ \\
\hline Suwan-1-SR & $7.03 \mathrm{a}$ & $10.81 \mathrm{a}$ & $11.52 \mathrm{a}$ & $12.07 \mathrm{a}$ & $9.04 \mathrm{a}$ & $10.96 a$ & $12.52 \mathrm{a}$ & $14.00 \mathrm{a}$ \\
\hline $\mathrm{SE} \pm$ & 0.10 & 0.23 & 0.17 & 0.18 & 0.25 & 0.26 & 0.27 & 0.20 \\
\hline Interraction & & & & & & & & \\
\hline NxZ & NS & NS & NS & NS & NS & NS & NS & NS \\
\hline $\mathrm{NxV}$ & NS & NS & NS & NS & NS & NS & NS & NS \\
\hline $\mathrm{ZxV}$ & NS & NS & NS & NS & NS & NS & NS & NS \\
\hline $\mathrm{NxZxV}$ & NS & NS & NS & NS & NS & NS & NS & NS \\
\hline
\end{tabular}

Means for same column and factor followed by the same letter are not significantly different at $5 \%$ level of probability.

NS- Not Significant 
Volume 18, Number 2, October 2020, pp 39 - 53.

Adeyemo, A.J.

Table 6: Effects of nitrogen zinc and variety on yield of maize in Minna in 2018 and 2019 seasons

\begin{tabular}{|c|c|c|c|c|c|c|c|c|c|c|}
\hline & \multicolumn{3}{|c|}{2018} & \multicolumn{7}{|c|}{2019} \\
\hline & $\begin{array}{c}\text { Cob } \\
\text { Length } \\
(\mathrm{cm})\end{array}$ & $\begin{array}{c}1000 \\
\text { grain } \\
\text { weight (g) }\end{array}$ & $\begin{array}{l}\text { Grain yield } \\
\text { (kg/ha) }\end{array}$ & $\begin{array}{c}\text { Cob } \\
\text { weight } \\
(\mathrm{kg} / \mathrm{ha})\end{array}$ & $\begin{array}{c}\text { Stover yield } \\
(\mathrm{kg} / \mathrm{ha})\end{array}$ & $\begin{array}{c}\text { Cob } \\
\text { Length } \\
(\mathrm{cm})\end{array}$ & $\begin{array}{c}1000 \\
\text { grain } \\
\text { weight }(\mathrm{g})\end{array}$ & $\begin{array}{l}\text { Grain yield } \\
\text { (kg/ha) }\end{array}$ & $\begin{array}{c}\text { Cob } \\
\text { weight } \\
(\mathrm{kg} / \mathrm{ha})\end{array}$ & $\begin{array}{c}\text { Stover yield } \\
\text { (kg/ha) }\end{array}$ \\
\hline \multicolumn{11}{|l|}{$\begin{array}{l}\text { Nitrogen } \\
\text { (N) }\end{array}$} \\
\hline 0 & $12.94 \mathrm{a}$ & $417.84 \mathrm{a}$ & $1895.8 \mathrm{c}$ & $379 a$ & $2302.1 \mathrm{c}$ & $11.26 \mathrm{a}$ & $397.15 b$ & $1747.20 \mathrm{c}$ & $336 b$ & $1953.51 \mathrm{c}$ \\
\hline 30 & $12.57 \mathrm{a}$ & $429.20 \mathrm{a}$ & $2308.4 b$ & $383 a$ & $2654.2 \mathrm{bc}$ & $13.39 \mathrm{a}$ & $434.77 \mathrm{a}$ & $2375.71 b$ & $391 b$ & $2737.31 b$ \\
\hline 60 & $13.29 \mathrm{a}$ & $436.18 \mathrm{a}$ & $2783.7 \mathrm{a}$ & $450 \mathrm{a}$ & $2839.7 \mathrm{ab}$ & $14.65 a$ & $443.80 \mathrm{a}$ & $2867.11 \mathrm{a}$ & $463 \mathrm{ab}$ & $2904.12 \mathrm{ab}$ \\
\hline 90 & $24.15 a$ & $430.81 \mathrm{a}$ & $2512.4 \mathrm{ab}$ & $2933 a$ & $3145.8 \mathrm{a}$ & $25.38 \mathrm{a}$ & $438.46 a$ & $2593.2 \mathrm{ab}$ & $1938.12 \mathrm{a}$ & $3326.71 \mathrm{a}$ \\
\hline $\mathrm{SE} \pm$ & 3.10 & 12.63 & 144.39 & 652.62 & 170.71 & 3.08 & 12.61 & 144.60 & 25.76 & 170.82 \\
\hline \multicolumn{11}{|l|}{ Zinc $(Z)$} \\
\hline 0 & $13.22 \mathrm{a}$ & $446.83 a$ & $2007.5 b$ & $2312 a$ & $2518.8 b$ & $13.48 \mathrm{a}$ & $418.07 \mathrm{a}$ & $1402.51 b$ & $399 c$ & $2477.71 b$ \\
\hline 2.5 & $12.70 \mathrm{a}$ & $417.60 \mathrm{a}$ & $2426.6 a$ & $396 a$ & $2685.9 b$ & $13.23 \mathrm{a}$ & $445.89 \mathrm{a}$ & $2430.72 \mathrm{a}$ & $406 \mathrm{~b}$ & $2660.13 a$ \\
\hline 5 & $21.29 \mathrm{a}$ & $421.09 \mathrm{a}$ & $2441.2 \mathrm{a}$ & $400 \mathrm{a}$ & $3001.6 \mathrm{a}$ & $21.82 \mathrm{a}$ & $421.67 \mathrm{a}$ & $2484.11 \mathrm{a}$ & $1291.11 \mathrm{a}$ & $2978.52 \mathrm{a}$ \\
\hline $\mathrm{SE} \pm$ & 3.00 & 10.65 & 135.79 & 647.03 & 155.03 & 3.07 & 11.22 & 152.04 & 21.27 & 171.58 \\
\hline \multicolumn{11}{|l|}{ Variety (V) } \\
\hline $\begin{array}{l}\text { Oba Super } \\
2\end{array}$ & $18.62 \mathrm{a}$ & $422.34 \mathrm{a}$ & $2374.5 a$ & $400 \mathrm{a}$ & $2616.7 \mathrm{a}$ & $19.06 \mathrm{a}$ & $422.38 \mathrm{a}$ & $2345.21 \mathrm{a}$ & $401.21 b$ & $2586.00 \mathrm{a}$ \\
\hline $\begin{array}{l}\text { Suwan-1- } \\
\text { SR }\end{array}$ & $12.85 \mathrm{a}$ & $434.67 \mathrm{a}$ & $2475.7 \mathrm{a}$ & $1672 \mathrm{a}$ & $2854.2 \mathrm{a}$ & $13.28 \mathrm{a}$ & $434.71 \mathrm{a}$ & $2446.31 \mathrm{a}$ & $1062.42 \mathrm{a}$ & $2824.80 \mathrm{a}$ \\
\hline $\mathrm{SE} \pm$ & 2.90 & 8.85 & 109.95 & 643.26 & 129.00 & 2.96 & 9.24 & 122.73 & 19.18 & 142.38 \\
\hline \multicolumn{11}{|l|}{ Interraction } \\
\hline $\mathrm{NxZ}$ & NS & NS & NS & NS & NS & NS & NS & NS & NS & $*$ \\
\hline $\mathrm{NxV}$ & NS & NS & NS & NS & NS & NS & NS & NS & NS & $*$ \\
\hline $\mathrm{ZxV}$ & NS & NS & NS & NS & NS & NS & NS & NS & NS & NS \\
\hline $\mathrm{NxZxV}$ & NS & NS & NS & NS & NS & NS & NS & NS & NS & $*$ \\
\hline
\end{tabular}

Means for same column and factor followed by the same subscript letters are not significantly different at $5 \%$ level of probability.

NS- Not Significant 
Journal of Agriculture and Food Sciences 39 - 53

Afolabi, S.G., Ewulo, B.S., Aiyelari, O.P.,

Adeyemo, A.J. 52

Volume 18, Number 2, October 2020, pp

Table 7: Interaction effects of nitrogen and zinc on stover yield in 2019 season in Minna

\begin{tabular}{lll}
\hline Nitrogen & Zinc & Stover yield $(\mathrm{kg} / \mathrm{ha})$ \\
\hline 0 & 0 & $1812.50 \mathrm{~d}$ \\
0 & 2.5 & $1850.0 \mathrm{~d}$ \\
0 & 5 & $2197.9 \mathrm{~cd}$ \\
30 & 0 & $2701.5 \mathrm{bcd}$ \\
30 & 2.5 & $3248.4 \mathrm{~b}$ \\
30 & 5 & $2762.1 \mathrm{bcd}$ \\
60 & 0 & $2695.8 \mathrm{bcd}$ \\
60 & 2.5 & $2645.80 \mathrm{bcd}$ \\
60 & 5 & $2870.8 \mathrm{bc}$ \\
90 & 0 & $2700.8 \mathrm{bcd}$ \\
90 & 2.5 & $2895.8 \mathrm{bc}$ \\
90 & 5 & $4083.3 \mathrm{a}$ \\
SE \pm & & 265.36 \\
\hline
\end{tabular}

Means in a column followed by the same subscript letters are not significantly different at $5 \%$ level of probability.

Table 8: Interaction effects of nitrogen and variety on stover yield in 2019 season in Minna

\begin{tabular}{lll}
\hline Nitrogen & Variety & Stover yield $(\mathrm{kg} / \mathrm{ha})$ \\
\hline 0 & Oba Super 2 & $1630.50 \mathrm{c}$ \\
0 & Suwan-1-SR & $2276.40 \mathrm{bc}$ \\
30 & Oba Super 2 & $2803.50 \mathrm{ab}$ \\
30 & Suwan-1-SR & $3004.60 \mathrm{ab}$ \\
60 & Oba Super 2 & $2912.50 \mathrm{ab}$ \\
60 & Suwan-1-SR & $2562.50 \mathrm{~b}$ \\
90 & Oba Super 2 & $2997.50 \mathrm{ab}$ \\
90 & Suwan-1-SR & $3455.80 \mathrm{a}$ \\
SE \pm & & 225.47 \\
\hline
\end{tabular}

Means in a column followed by the same letters are not significantly different at $5 \%$ level of probability. 
Journal of Agriculture and Food Sciences 39 - 53

Afolabi, S.G., Ewulo, B.S., Aiyelari, O.P.,

Adeyemo, A.J. 53

Volume 18, Number 2, October 2020, pp

Table 9: Interaction effects of nitrogen zinc and variety on stover yield in 2019 season in Minna

\begin{tabular}{|c|c|c|c|}
\hline Nitrogen & Zinc & Variety & $\begin{array}{ll}\text { Stover } & \text { yield } \\
(\mathrm{kg} / \mathrm{ha}) & \end{array}$ \\
\hline 0 & 0 & Oba Super 2 & $1000.0 \mathrm{~h}$ \\
\hline 0 & 2.5 & Oba Super 2 & $1412.5 \mathrm{gh}$ \\
\hline 0 & 5 & Oba Super 2 & 2479.1def \\
\hline 0 & 0 & Suwan-1-SR & 2625.0cdef \\
\hline 0 & 2.5 & Suwan-1-SR & $2287.5 \mathrm{defg}$ \\
\hline 0 & 5 & Suwan-1-SR & $1916.6 f g$ \\
\hline 30 & 0 & Oba Super 2 & 2773.0cdef \\
\hline 30 & 2.5 & Oba Super 2 & $2562.5 \mathrm{cdef}$ \\
\hline 30 & 5 & Oba Super 2 & $3075.0 \mathrm{bcde}$ \\
\hline 30 & 0 & Suwan-1-SR & 2630.0cdef \\
\hline 30 & 2.5 & Suwan-1-SR & $3934.7 \mathrm{ab}$ \\
\hline 30 & 5 & Suwan-1-SR & $2449.1 \mathrm{def}$ \\
\hline 60 & 0 & Oba Super 2 & 3183.3bcde \\
\hline 60 & 2.5 & Oba Super 2 & 2270.8defg \\
\hline 60 & 5 & Oba Super 2 & $3283.3 \mathrm{bcd}$ \\
\hline 60 & 0 & Suwan-1-SR & $2208.3 \mathrm{efg}$ \\
\hline 60 & 2.5 & Suwan-1-SR & $3020.8 \mathrm{bcde}$ \\
\hline 60 & 5 & Suwan-1-SR & 2458.3def \\
\hline 90 & 0 & Oba Super 2 & $2825.8 \mathrm{cdef}$ \\
\hline 90 & 2.5 & Oba Super 2 & $2583.3 \mathrm{cdef}$ \\
\hline 90 & 5 & Oba Super 2 & $3583.3 \mathrm{bc}$ \\
\hline 90 & 0 & Suwan-1-SR & $2575.8 \mathrm{cdef}$ \\
\hline 90 & 2.5 & Suwan-1-SR & $3208.3 \mathrm{bcde}$ \\
\hline 90 & 5 & Suwan-1-SR & $4583.3 \mathrm{a}$ \\
\hline $\mathrm{SE} \pm$ & & & 237.34 \\
\hline
\end{tabular}

Means in a column followed by the same subscript letters are not significantly different at $5 \%$ level of probability. 